\title{
Magnesium Status and Stress: The Vicious Circle Concept Revisited
}

\author{
Gisèle Pickering ${ }^{1}$, André Mazur ${ }^{2}$, Marion Trousselard ${ }^{3}{ }^{\circ}$, Przemyslaw Bienkowski ${ }^{4}$, \\ Natalia Yaltsewa ${ }^{5}$, Mohamed Amessou ${ }^{6} \oplus$, Lionel Noah ${ }^{6, *}$ and Etienne Pouteau ${ }^{6}$ \\ 1 Plateforme d'Investigation Clinique/CIC Inserm 1405, University Hospital CHU, \\ 63000 Clermont-Ferrand, France; gisele.pickering@uca.fr \\ 2 INRAE, UNH, Unité de Nutrition Humaine, Université Clermont Auvergne, \\ 63001 Clermont-Ferrand, France; andre.mazur@inrae.fr \\ 3 Independent Regulatory Board for Auditors (IRBA), 91220 Bretigny-sur-Orge, France; \\ marion.trousselard@gmail.com \\ 4 Department of Psychiatry, Warsaw Medical University, 02-091 Warsaw, Poland; pbienko@yahoo.com \\ 5 Department of General Medicine, The Yaroslavl State Medical University Institute \\ of Postgraduate Education, 150000 Yaroslavl, Russia; yaltzewa@yandex.ru \\ 6 Medical Affairs Department, Consumer HealthCare, Sanofi, Gentilly, 94250 Paris, France; \\ Mohamed.Amessou@sanofi.com (M.A.); Etienne.Pouteau@sanofi.com (E.P.) \\ * Correspondence: Lionel.Noah@sanofi.com; Tel.: +33-06-0213-6165
}

Received: 11 November 2020; Accepted: 25 November 2020; Published: 28 November 2020

\begin{abstract}
Magnesium deficiency and stress are both common conditions among the general population, which, over time, can increase the risk of health consequences. Numerous studies, both in pre-clinical and clinical settings, have investigated the interaction of magnesium with key mediators of the physiological stress response, and demonstrated that magnesium plays an inhibitory key role in the regulation and neurotransmission of the normal stress response. Furthermore, low magnesium status has been reported in several studies assessing nutritional aspects in subjects suffering from psychological stress or associated symptoms. This overlap in the results suggests that stress could increase magnesium loss, causing a deficiency; and in turn, magnesium deficiency could enhance the body's susceptibility to stress, resulting in a magnesium and stress vicious circle. This review revisits the magnesium and stress vicious circle concept, first introduced in the early 1990s, in light of recent available data.
\end{abstract}

Keywords: stress; magnesium; hypomagnesemia; magnesium deficiency; vicious circle; dietary intake; magnesium supplementation

\section{Introduction}

Stress, often intended as a psychological response to external stressors, has become a common issue of modern life [1]. From a neurobiology perspective, stress is an adaptive system that continuously assesses and interacts physically, physiologically, or psychosocially, with the environment. When this stress system is overloaded, negative health outcomes could result [2]. Magnesium is a fundamental nutrient, the role of which in human health is widely recognized [3]. Today, magnesium deficiency is also a common condition among the general population [4], and given its importance in the functioning of many reactions of the human body, this deficiency can increase the risk of physical and mental health illness over time. Of note, symptoms of magnesium deficiency and stress are very similar, the most common being fatigue, irritability, and mild anxiety [5-7]; further symptoms are shown in Table 1. 
Table 1. Symptoms of magnesium deficiency and symptoms of stress.

\begin{tabular}{cc}
\hline Most Frequently Reported Symptoms of Stress [6,7] & Symptoms of Magnesium Deficiency [5,8] \\
\hline Fatigue & Tiredness \\
Irritability or anger & Irritability \\
Feeling nervous & Mild anxiety/nervousness \\
Lack of energy & Muscle weakness \\
Upset stomach & Gastrointestinal spasms \\
Muscle tension & Muscle cramps \\
Headache & Headache \\
Sadness/depression & Mild sleep disorders \\
Chest pain/hyperventilation & Nausea/vomiting \\
\hline
\end{tabular}

Note: Similar symptoms are highlighted in bold.

The idea of a bidirectional relationship between magnesium and stress was first introduced by Galland and Seelig, in the early 1990s [9,10] and then referred to as the vicious circle. This vicious circle implies that stress can increase magnesium loss, causing a deficiency; in turn, magnesium deficiency can enhance the body's susceptibility to stress [10].

Taking into account the increasing prevalence of stress in modern societies [11], and its related consequences to health, this review revisits the magnesium and stress vicious circle concept, with a focus on the role of magnesium on the body's response to stress and the pathways that regulate such a response. In particular, the scope of this article was to assess the evidence available on the need of an adequate intake of magnesium, and strengthen the hypothesis that a revision of the current recommended intake of magnesium is needed for the general population when exposed to stress, in order to reduce associated health risks.

\section{Magnesium: Biological Role and Dietary Needs}

\subsection{Biological Role of Magnesium and Homeostasis}

Magnesium is an essential mineral for humans [12]. Being the second most abundant intracellular cation [5], magnesium is involved in almost all major metabolic and biochemical processes [13]. It acts as a cofactor in hundreds of enzymatic reactions [13], its primary functions including protein and nucleic acid synthesis, regulation of metabolic pathways, neuronal transmission, neuromuscular function, and regulation of cardiac rhythm $[8,14,15]$. In addition, magnesium is a naturally occurring calcium channel blocker, is involved in the maintenance of electrolyte balance (e.g., regulation of sodium-potassium ATPase activity), and plays a key role in membrane excitability $[5,12]$.

It is estimated that an adult human body contains around 21-28 g of magnesium, 50-60\% of which is stored in the bones, with the remainder distributed in soft tissues such as muscles $[14,16]$. Magnesium is also an essential component of the extracellular fluid (ECF) and the cerebrospinal fluid (CSF) in the central nervous system $[17,18]$. Magnesium enters the brain through the blood-brain barrier which maintains the passage of nutrients and electrolytes for the ECF homeostasis, and is actively transported by choroidal epithelial cells into the CSF $[17,18]$. Although little has been revealed about the exact mechanisms of magnesium transport into the brain, it is known that magnesium concentration is higher in the CSF than in plasma [19]. Under conditions of deficiency, magnesium levels still decline in the CSF, but slower when compared to the changes observed in plasma magnesium levels [19]. Experimental studies have shown that in magnesium-deficient animals, the brain uptake of magnesium is almost doubled compared to normal-fed controls [20] and CFS magnesium concentration was readily repleted, showing that magnesium is an essential mineral for the brain homeostasis $[19,20]$.

Only $1 \%$ of the total magnesium is extracellular and $0.3 \%$ of this circulates in serum in three different forms [21]: Free (unbound; 60\%), which represents the biologically active form; albumin-bound (30\%); or in a complex with other ions (10\%) [13]. 
Magnesium homeostasis is tightly regulated and relies on the dynamic balance between intestinal absorption, kidney excretion, and storage in bones (Figure 1) [22]. Magnesium is mainly absorbed in the distal parts of the small intestine [22], and mostly stored in bones [22], where it serves as a reservoir to maintain the equilibrium with its extracellular concentration [22]. The kidneys play a critical part in magnesium homeostasis by eliminating its excess [22].

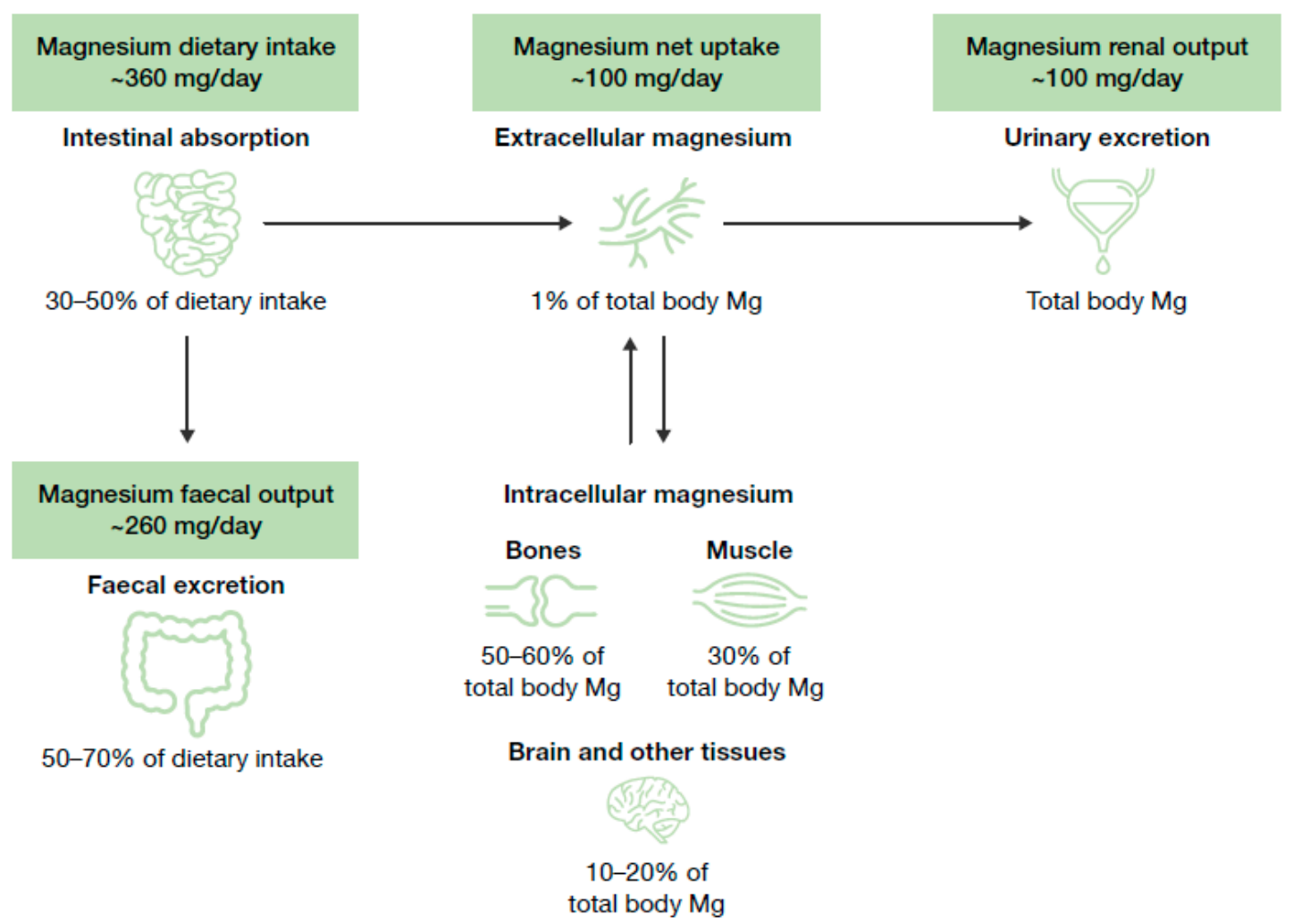

Figure 1. Magnesium homeostasis. Figure adapted from Jahnen-Dechent, 2012 [17]. Data from Elin, 1988 [19] and deBaaij, 2015 [8]. Mg, magnesium.

Many factors can affect magnesium balance: A diet high in sodium, calcium, and protein [5,23-25], the consumption of caffeine and alcohol [5,13,26], and the use of certain medicines such as diuretics, proton-pump, and inhibitors or antibiotics [13,26,27], which can all cause lower magnesium retention. In healthy individuals, some physiological conditions such as pregnancy [28,29], menopause [30], or ageing [31,32] are associated with changes in the need for magnesium. Pathological conditions, particularly those affecting the absorption and the elimination of nutrients (e.g., diabetes, renal function impairment, and physiological stress), may also result in significant magnesium loss or malabsorption $[4,5,26,33,34]$. Studies on hereditary forms of magnesium deficiency have contributed to the identification of both recessive and dominant genetic disorders directly affecting the transport of magnesium at a cellular level [35]. Although mutated transporting-proteins mainly contribute to renal wasting or intestinal malabsorption of magnesium, the mechanisms at the molecular level remain to be elucidated $[8,36]$. Notably, several studies showed that lower magnesium levels are involved in the course of several mental disorders, especially depression [37]. A summary of the factors affecting magnesium homeostasis is presented in Table 2. 
Table 2. Factors contributing to magnesium deficiency.

\begin{tabular}{|c|}
\hline Diet related \\
\hline Inadequate magnesium intake $[5,13,26]$ \\
\hline High protein diet $[5,25]$ \\
\hline High sodium diet $[5,25]$ \\
\hline High calcium diet $[5,23-25]$ \\
\hline High caffeine intake [5] \\
\hline Alcohol dependence $[5,13,26]$ \\
\hline Lifestyle \\
\hline Sports $[25,38-40]$ \\
\hline Sleep quality and quantity $[41,42]$ \\
\hline Chronic stress $[43,44]$ \\
\hline Pharmacological related \\
\hline Diuretics, e.g., furosemide $[13,26,27]$ \\
\hline Proton-pump inhibitors, e.g., omeprazole $[13,27]$ \\
\hline Cisplatin $[13,26,27]$ \\
\hline Antibiotics, e.g., gentamicin $[13,27]$ \\
\hline Physiological conditions \\
\hline Pregnancy $[28,29]$ \\
\hline Ageing $[31,32]$ \\
\hline Menopause [30] \\
\hline Pathological conditions \\
\hline Genetic disorders $[8,35,36]$ \\
\hline Type 2 diabetes mellitus $[4,5]$ \\
\hline Gastrointestinal disorders $[5,26]$ \\
\hline Kidney failure $[5,33]$ \\
\hline Cardiovascular diseases $[5,45]$ \\
\hline Metabolic syndrome $[5,34]$ \\
\hline Osteoporosis $[15,25,33]$ \\
\hline
\end{tabular}

\subsection{Food Sources, Current Recommended Intakes and Safety}

Nuts, legumes, whole cereals, and fruits have the highest magnesium content of all foods [16]. Coffee or cocoa-based products may also contain significant amounts of magnesium, while fish, meats, and milk have an intermediate amount [46,47]. Drinking water, especially harder water, can also be rich in magnesium salts [48]. The source of dietary magnesium varies widely according to gender, age, and dietary habits. For example, French adults in 2016 obtained more than $21 \%$ of their magnesium from hot beverages including coffee, $9 \%$ from bread, and $6 \%$ from vegetables [47], whereas in a sample of American adults, the main sources of magnesium were vegetables $(13 \%)$, milk $(7 \%)$ and meat (7\%) [49]. In a sample of Polish adults, dietary magnesium requirements were mostly maintained by the consumption of cereal products (11.8-15.3\%) [50], and milk or dairy products (10.9\%) [51]. A study investigating the Italian diet found that cereals (27\%) are the primary source of magnesium in adults [52].

Over time, public health agencies have reviewed and established recommendations for dietary intake of magnesium (and other nutrients). These include the estimated average requirement (EAR), which represents the average daily intake that satisfies the nutritional requirement of $50 \%$ of the population considered; and the recommended dietary allowance (RDA), which is the daily intake that meets the requirement of $97.5 \%$ of the same population [15,53]. Values are set on the basis of dietary balance experiments and/or results from clinical studies and meta-analyses [54-57].

Dietary balance studies performed in the 1980s in the USA concluded that the EAR for magnesium was 310-330 in men and 255-265 mg/day in women [55-57]. As a consequence, in 1997, the Standing Committee on the Scientific Evaluation of Dietary Reference Intakes (for the USA and Canada) 
set an RDA of 400-420 and 310-320 mg/day for men and women, respectively [58]. Nowadays, nutrient requirements and dietary guidelines are available in every country. For instance, in Poland, the RDA for magnesium is 400-420 for men and 310-320 mg/day for women [59], and in Russia, it is $300 \mathrm{mg} /$ day for both men and women [60]. The European Food Safety Agency (EFSA) did not consider the available scientific evidence strong enough to determine RDAs, and has suggested an "adequate intake" of 350 and $300 \mathrm{mg} /$ day for men and women, respectively [16]. Within the EU, national governmental bodies have set local RDAs. In 2015, the Japanese Ministry of Health, Labor and Welfare updated the dietary reference intake guidelines and set the RDA at 320-340 and 220-230 mg/day for adult men and women, respectively [61]. Recommended intakes are summarized by country in Table 3.

Table 3. Current magnesium recommended dietary allowances (RDAs) across countries.

\begin{tabular}{|c|c|c|}
\hline \multirow{2}{*}{ Country } & \multicolumn{2}{|c|}{ Magnesium, mg/day } \\
\hline & Men & Women \\
\hline Italy [62] & 240 & 240 \\
\hline Russia [60] & 300 & 300 \\
\hline Japan [61] & $320-340$ & $220-230$ \\
\hline Poland [59] & $400-420$ & $310-320$ \\
\hline USA and Canada [58] & $400-420$ & $310-320$ \\
\hline France [63] & 420 & 360 \\
\hline
\end{tabular}

Studies have consistently shown that the dietary magnesium intake is often inadequate across different countries [5,64]. In 2005, King et al. reported that approximately $60 \%$ of Americans do not reach the recommended daily intake of magnesium through their diet [65]. In the USA, between 2003-2006, the average intakes of magnesium from food were 268 for men and $234 \mathrm{mg}$ for women, which meant that $63 \%$ of men and $69 \%$ of women did not meet the EAR [66]. These results were confirmed and supported by the Dietary Guidelines Advisory Committee, which, in 2015, concluded that magnesium is an under-consumed nutrient for many Americans [46].

In Europe, the situation is similar. The National Diet and Nutrition Survey conducted in the UK between 2014-2016 showed that men's mean dietary intake in magnesium was 302 and women's was $238 \mathrm{mg} /$ day [67]. In France in 2007, the mean daily dietary intake was 323 in men and $263 \mathrm{mg}$ in women and more than two-thirds of the French adult population $(67.4 \%$ of men and $76.7 \%$ of women, aged 18 to 54) had an inadequate magnesium intake [68]. Furthermore, in Spain, the Anthropometry, Intake and Energy Balance in Spain (ANIBES) study revealed that the mean consumption of magnesium in the population was $222 \mathrm{mg} /$ day, indicating that $79 \%$ of the population had an intake below $80 \%$ of the national RDA [69]. The Mediterranean Healthy Eating, Ageing, and Lifestyle (MEAL) observational study conducted in Italy found that the dietary intake of magnesium was adequate both in men (397) and women (390 mg/day), with cereals, dairy products, and legumes being the main food sources [70]. Lastly, an analysis based on national surveys conducted across European countries showed that the mean magnesium intake among adults (18-60 years old) in Poland was 396 in men and $264 \mathrm{mg} /$ day in women; [71] whereas German adults had the highest mean intake magnesium, 522 in men and $418 \mathrm{mg} /$ day in women [71].

When there is a need for optimizing the magnesium status, a variety of oral supplements are available. Magnesium supplementation is considered well-tolerated, with diarrhea typically being the main manifestation of an excessive intake [72]. The upper limit for magnesium supplementation in healthy adults is $350 \mathrm{mg} /$ day [73]. Normally, an increased renal filtration can reverse a wide range of serum magnesium concentration to normal levels. However, serious adverse effects have been reported for serum magnesium concentration exceeding 1.74-2.61 mmol/L. Symptoms of magnesium toxicity include hypotension, nausea, flushing of the face, retention of urine, and lethargy, and may progress to difficulty breathing, extreme hypotension, irregular heartbeat, and cardiac arrest [72]. 


\subsection{Magnesium Deficiency: Causes and Health Consequences}

In clinical practice, measurement of serum magnesium levels is the most common means of assessing nutrient status [13], with normal values considered to be within the $0.7-1.0 \mathrm{mmol} / \mathrm{L}$ range $[74,75]$. Hypomagnesemia is clinically defined when serum concentrations drop below $0.7 \mathrm{mmol} / \mathrm{L}$ [8]. Severe hypomagnesemia $(<0.4 \mathrm{mmol} / \mathrm{L})$ is rare and occurs mostly in serious pathological conditions [76]. Symptoms may include neuromuscular dysfunction (muscular weakness, tremors, seizures or tetany); cardiovascular signs (electrocardiographic abnormalities and arrhythmias); and hypokalemia and hypocalcemia [13]. However, mild hypomagnesemia $(0.5-0.7 \mathrm{mmol} / \mathrm{L})$ is common and estimated to affect around $2.5-15 \%$ of the population $[4,26]$. In the majority of cases, magnesium deficiency is not identified, as low serum levels are compensated by the release of magnesium from the bone reservoir [48]. In addition, mild deficiency can remain undetected as it often occurs with nonspecific symptoms such as irritability, nervousness, mild anxiety, muscle contractions, weakness, fatigue, and digestive troubles [26]. In addition, it has been suggested that chronic latent magnesium deficiency could start developing below $0.85 \mathrm{mmol} / \mathrm{L}$ with a potential impact on human health [12,77]. A recent study by Noah et al. found that nearly half ( 44\%) of the subjects screened for stress had chronic latent magnesium deficiency (defined as serum magnesium $<0.85 \mathrm{mmol} / \mathrm{L}$ ) [78]. Moreover, subclinical, chronic magnesium depletion may contribute to various dysfunctions and diseases and the scientific literature is rich in studies highlighting the association between low dietary magnesium intake and a higher risk of type 2 diabetes, cardiovascular diseases, osteoporosis, and metabolic syndrome $[8,79,80]$.

Several factors contribute to magnesium deficiency (Table 2). Dietary surveys point to an inadequate magnesium intake from food. Surveys conducted in different countries have consistently showed a substantial inadequate intake of magnesium from food in the general population, particularly in young adults, those over 70 years of age [81], and in women [71]. Of note, over the past 60 years, intensive farming practices have caused a significant depletion of the mineral content of the soil [82-84], including a decrease in magnesium of up to $30 \%[85,86]$. Additionally, western diets typically have a greater proportion of processed food, where several products are mostly refined, with magnesium being depleted by up to $80-90 \%$ in the process [5,8]. Factors and behaviors associated with the western lifestyle, including intense sport and physical activity [38], poor sleep quality and quantity [41], and psychological stress [43,44], can also induce magnesium loss. Magnesium deficiency is linked to many health conditions, from those affecting its metabolism, such as gastrointestinal diseases, type 2 diabetes, alcohol dependence, or kidney failure [5,26], to genetic disorders [35]. A growing body of evidence also suggests that chronic stress may cause magnesium loss/deficiency [43]. Numerous studies have shown lower magnesium levels associated with different neurological and psychiatric disorders, particularly depression and post-traumatic stress disorder $[87,88]$ but also anxiety disorders, attention deficit hyperactivity disorder, and bipolar disorder [37,89]. Although evidence on a causal factor between mental disorders and magnesium deficiency has yet to be confirmed, stress appears as a key component in the relationship between mental health illness and magnesium deficiency.

\section{Stress}

Stress is commonly described as a trigger that evokes a physiological and psychological response of the body [90]. Over the past decades, the understanding of stress biology has largely evolved. Stress is no longer considered as a temporary response to occasional threats, but rather an ongoing and adaptive system that enables an individual to assess, cope, and predict constantly changing conditions. However, the capacity of this stress system is limited and can be overloaded, resulting in poor health outcomes, particularly those related to mental illness like depression or cognitive deficits [2].

Stress not only affects the mental health status of an individual, but it is also characterized by a physical response of the body that, depending on the type and length of exposure, may lead to short-term effects (e.g., increased blood pressure, increased heart and respiration rates, increased alertness) [91], or long-term effects (e.g., impaired hippocampal neurogenesis, cognitive and memory disorders) [92]. 
The following sections summarize widely recognized theoretical models of stress and describe possible physiological roles of magnesium in the stress response. Here, the term "stress model" refers to a theoretical framework used to predict outcomes and to explain specific processes.

\subsection{Neurobiological Stress and Allostatic Load Model}

In the 1950s, Selye proposed the general adaptation syndrome model to describe stress as the reaction of the body to emergency situations [93]. This theory divides the response to stressful stimuli into three phases: (1) Alarm: Upon perceiving a stressor, the body reacts with a "fight-or-flight" response, the sympathetic nervous system (SNS) is stimulated, and the body's resources are mobilized to meet the threat. (2) Resistance: The body resists and compensates as the parasympathetic nervous system (PNS) attempts to return many physiological functions to normal levels, while the body remains on alert and focuses resources against the stressor. (3) Exhaustion: If the stressor continues beyond the body's capacity, the resources are depleted and the body becomes susceptible to disease (distress) [91,93].

A more contemporary concept, which better describes the cumulative impact of stressor exposure on health outcomes, is that of allostasis. Allostasis is the process by which constant changes allow an organism to achieve and maintain normal functions, thus reflecting the ability of the body to adapt to daily situations like exercising or hunger, effectively [94]. However, this continual maintenance costs the body energy and resources, and over time, may lead to symptoms of allostatic load-the functional and structural damage caused by "the wear and tear" of the body's resources in response to stress [95]. Therefore, the response to a new stressor depends on the body's resources available following the previous stress response [96]. The allostatic load is characterized by a cumulative effect, which becomes greatest when stress is chronic or intense [96].

The hypothalamic-pituitary-adrenal (HPA) axis and the autonomic nervous system (comprising SNS and PNS) have been identified as the mediators of this neurobiological stress model $[90,91,95]$. First, corticotrophin-releasing factor (CRF) is secreted from the paraventricular nucleus in the hypothalamus; the subsequent secretion of adrenocorticotropic hormone (ACTH) from the anterior pituitary stimulates the release of glucocorticoids (mainly cortisol) from the adrenal cortex [97]. Noradrenaline (NA) and adrenaline are also released from the sympathetic nerves and the adrenal medulla, and together with the glucocorticoids regulate the stress response [90,91]. Cortisol also interacts with the serotonergic pathway, adjusting the release of serotonin (5-hydroxytryptamine or 5-HT) neurotransmitter in response to acute or chronic stressors [98]. Serotoninergic neurons modulate the stress response either via direct neurotransmission to the hypothalamus, or by stimulation of noradrenergic neurons [97]. In addition to the regulation through feedback mechanisms, the HPA axis is also modulated by other central systems, particularly by the inhibitory action of the $\gamma$-aminobutyric acid (GABA), and the excitatory effect of glutamate [99].

In this neurobiological model, cortisol is a well-known mediator of the stress response. The nocturnal cortisol urinary excretion in apparently healthy subjects reflects the basal tone of the HPA axis [100]; conversely, the blood cortisol concentration measured in a challenging environment is a sign of stress activity [101]. It has been shown that cortisol coordinates the central response to stress at several levels [102], and indirectly influences mechanisms of neuroprotection [103]. Neurotrophic factor production, represented by the brain-derived neurotrophic factor (BNDF), intervenes in allostasis through protecting neurons [104]. Normally, BNDF promotes neuronal survival and plasticity [104]; however, changes in BNDF expression have been reported following exposure to stressful stimuli. An increase of BNDF has been observed in response to moderate stress [105], whereas a decrease has been associated with high levels of stress [106]. Furthermore, increasing evidence shows a link between cortisol responses and oxidant elevation [107]. The accumulation of free radicals and other reactive oxygen species is also a sign of allostatic load, resulting from the imbalance between cellular metabolic activities and antioxidant defense mechanisms [108,109]. 
Noteworthy, magnesium interacts with all these stress mediators [17,110-112], overall serving an inhibitory function in the regulation and central neurotransmission of the stress response (details of these interactions are summarized in chapter 6).

\subsection{Generalized Unsafety Theory of Stress (GUTS) Model}

Conventional theories of stress have historically focused on the assumption that stress is a response to an actual environmental threat (either internal or external to the body), making it difficult to explain the relation between stress and disease. In contrast, GUTS is a new psychological and cognitive theoretical model proposed by Brosschot in 2016 [113] that revises and expands the stress theory by focusing on safety instead of threat, and by including risk factors that have hitherto not been attributed to stress [113]. Based on neurobiological and evolutionary evidence, GUTS hypothesizes that stressors are not necessary for a chronic stress response to occur but the perception of an unsafe state is enough. In GUTS, PNS is the key system controlling the stress response (particularly the vagus nerve and the prefrontal cortex activity) [113]. Of note, preclinical data suggest that magnesium may be important for the functionality of these central systems. An excess of magnesium or magnesium deficiency have been shown to modulate the autonomic nervous system, but further research is still needed [114-116].

The GUTS model suggests that the default stress response can be chronically activated in various situations, three of which are particularly susceptible to health risks. (1) Reduced body capacity: In compromised physical conditions, e.g., obesity or aging, the brain perceives the body as inadequate to be able to "fight-or-flight", and therefore maintains a state of general alarm, or unsafety [117]. (2) Compromised social network: Being part of a group is a fundamental aspect of survival for social animals and humans, and isolation is one of the main conditions in which safety is lacking [117]. Interestingly, there is evidence that patients suffering from metabolic syndrome [118] or congestive heart failure [5] (both conditions of reduced body capacity as described in GUTS) exhibit lower serum magnesium concentration. (3) Perceived aversive environment: In cases of specific stressors (e.g., work stressors), a neutral daily environment (e.g., an office working environment) can be perceived as unsafe [117]. The GUTS model suggests that repetitive negative thinking may result in the impairment of key systems controlling the stress response [119]; however, the relationship between general unsafety and magnesium status is to be elucidated yet.

\section{Evidence of the Impact of Stress on Magnesium Homeostasis}

Initially, the shift from intracellular to extracellular magnesium following a stressor exposure plays a protective and regulatory role [90]. Normally, magnesium inhibits the glutamatergic transmission while promoting GABA activity, resulting in a mostly inhibitory effect at the central level [42]. Magnesium also tends to diminish the stress response mediated by catecholamines and glucocorticoids. However, a chronic stressor exposure may result in a depletion of various resources as described by Selye, including magnesium $[42,93]$. The progressive loss of magnesium from the reservoir in bone can eventually compromise its physiological inhibitory action and lead to an over-activation of the HPA axis and neuronal hyperactivity [120]. The impact of stress on magnesium status has been extensively investigated in both animal and human studies [42,121].

Pre-clinical evidence. Animal studies have shown a transient hypermagnesemia in the short-term period after the exposure to acute stress stimuli [122-125]. A series of experiments conducted on cats by Classen et al. showed that stimuli such as withdrawal of blood, infusion of catecholamines, or potassium poisoning all caused an increase of blood magnesium concentration [122]. This increase was not influenced by pre-treatment with an adrenergic blocking agent (e.g., reserpine), suggesting that other mechanisms rather than catecholamines are responsible for the change in magnesium levels [122]. Similarly, a shift of magnesium from erythrocytes to serum was reported in different studies investigating the effect of acute noise on magnesium-deficient guinea pigs [123] and rats. As a consequence, a net renal excretion of magnesium occurs, leaving the animal magnesium deficient. 
Mild hypomagnesemia can be observed in response to mid- or long-term exposure to stress. A study conducted on guide dog candidates at different levels of a training program (elementary, intermediate, and advanced) showed the effects of temperature and physical stress on serum magnesium levels. First, it was demonstrated that serum magnesium levels were significantly lower in winter than in summer (average temperature was 6 and $29^{\circ} \mathrm{C}$, respectively), suggesting an impact of seasonality on magnesium homeostasis. Thereafter, it was noticed that physical exercise had a greater impact on serum magnesium levels of dog candidates in the elementary class compared to more trained ones. These results were lastly confirmed by a third experiment, assessing both the impact of physical stress and temperature on serum magnesium levels and finding that serum magnesium levels after exercise were significantly lower in winter than in summer. [126]. The impact of physical stressors was assessed also in another study conducted on rats. A greater serum magnesium reduction was observed in those administrated with ethanol and then exposed to restraint stress, compared to control rats facing the same restraint test but receiving water [127]. An additional study conducted by Heroux et al. on rats fed with a magnesium-deficient diet and kept at low temperature $\left(6^{\circ} \mathrm{C}\right)$ for about 17 months found that the studied animals were capable of adapting to cold stress despite suboptimal magnesium intake; initial signs of magnesium deficiency (including skin sores, reduced growth rate, lower levels of magnesium in most organs) gradually disappeared after two months. However, regardless this adaptation, the long-term stress resistance (measured as cold resistance at $-20^{\circ} \mathrm{C}$ ) of magnesium-deficient rats was reported to decline over time when compared to controls [128]. Lastly, exposure to cold $\left(2-5^{\circ} \mathrm{C}\right)$ and a deficient dietary intake of magnesium significantly reduced plasma magnesium in sheep, whereas no effect was observed in normally fed sheep [129].

Clinical evidence. To help elucidate the stress hormone-induced magnesium deficiency and its clinical relevance, Whyte et al. investigated the effect produced by the infusion of adrenaline on plasma magnesium concentrations [130]. They found that magnesium levels were significantly reduced not only during the infusion time but also an hour after test cessation, without any sign of recovery [130]. A variety of tests have demonstrated that magnesium levels, both in serum and urine, are affected by the exposure to stress stimuli. Significant reductions in plasma and total magnesium concentrations were reported in a 3-month analysis on young adults exposed to either chronic or sub-chronic stressful conditions (e.g., acts of intolerance or fear of military actions) [43]. A similar effect was also seen in a study investigating the effect of temporary (one day) and chronic (one month) sleep deprivation on magnesium levels; in a group of otherwise healthy men, chronic sleep restriction was associated with greater reductions in erythrocyte magnesium concentrations [131]. University students during an exam period reported an increase in anxiety that was also associated with an increased urinary excretion of magnesium [44]. In a similar study conducted on college students during the 4 weeks following an examination period, erythrocyte magnesium content was found to be significantly depleted [132]. Interestingly, the variations in blood and urine magnesium levels were confirmed by Mocci et al. who studied the effect of noise on catecholamines and magnesium serum and urinary excretions on healthy men [133]. Mocci and his study group also noted how the timing for the change to occur was very different between the two variables, with serum magnesium increasing a few hours after the exposure to the noise (probably reflecting extracellular flux immediately after the stress), and urine excretion reaching a peak in a few hours but lasting up two days [133]. A similar result was reported by Ising et al. on a study investigating the effect of traffic noise on workers' performance. Under noise stress $(7 \mathrm{~h})$, a decrease in erythrocyte magnesium levels was observed, followed by an increase of serum levels and urine excretion of magnesium [134]. The impact of acute stress on transient hypermagnesemia was noted also under physical stress. Short- and long-term exercise (20 min versus $1 \mathrm{~h}$, respectively) had a different influence on the plasma magnesium levels: an increase of plasma magnesium was reported after short-term exercise but not after long-term exercise. However, after both physical tests, magnesium levels dropped below the pre-exercise values [135]. A summary of the pre-clinical and clinical evidence is shown in Table 4. 
Table 4. Summary of the pre-clinical and clinical evidence supporting the impact of stress on magnesium homeostasis.

\begin{tabular}{|c|c|c|c|}
\hline \multicolumn{4}{|c|}{ Evidence of the Impact of Stress on Magnesium Homeostasis } \\
\hline & Population Tested & Stress Stimulus & Impact on Magnesium \\
\hline \multirow{8}{*}{ Pre-clinical } & $\begin{array}{c}\text { Cats } \\
(N=30)\end{array}$ & $\begin{array}{l}\text { Withdrawal of blood; infusion of } \\
\text { catecholamines; potassium poisoning }\end{array}$ & $\uparrow$ Blood Mg [122] \\
\hline & Guinea pigs (41) & Noise & $\uparrow$ Serum Mg, $\downarrow$ Erythrocytes Mg [123] \\
\hline & Rats (88) & Noise & $\uparrow$ Serum Mg, $\downarrow$ Erythrocytes Mg [124] \\
\hline & Rats & Noise & $\downarrow$ Serum Mg, $\downarrow$ Erythrocytes Mg \\
\hline & Dogs & Physical exercise, temperature & $\downarrow$ Serum Mg [126] \\
\hline & Rats & Ethanol/Restraint stress & $\downarrow$ Serum Mg [127] \\
\hline & Rats & Cold & $\downarrow$ Tissue content of Mg [129] \\
\hline & Sheep & Dietary $\mathrm{Mg}$ restriction, cold & $\downarrow$ Plasma Mg [129] \\
\hline \multirow{8}{*}{ Clinical } & Adults $(N=8)$ & Adrenaline infusion & $\downarrow$ Plasma Mg [130] \\
\hline & Young adults $(N=35)$ & $\begin{array}{l}\text { Chronic or sub-chronic } \\
\text { psychological stress }\end{array}$ & $\downarrow$ Plasma Mg [43] \\
\hline & Healthy men $(N=16)$ & Chronic sleep deprivation & $\downarrow$ Erythrocyte Mg [131] \\
\hline & Young adults $(N=35)$ & University exams & $\uparrow$ Urinary Mg [44] \\
\hline & Young adults $(N=30)$ & University exams & $\downarrow$ Erythrocyte Mg [132] \\
\hline & Young adults $(N=25)$ & Noise & $\uparrow$ Urinary Mg $\uparrow$ Serum Mg [133] \\
\hline & Healthy men (56) & Noise & $\begin{array}{c}\uparrow \text { Serum Mg, } \downarrow \text { Erythrocytes Mg; } \\
\uparrow \text { Urinary Mg [134] }\end{array}$ \\
\hline & Healthy men & Short- and long-term physical exercise & $\uparrow$ Plasma Mg [135] \\
\hline
\end{tabular}

$\mathrm{Mg}$, magnesium; $\uparrow$, increase; $\downarrow$, decrease.

\section{Evidence of the Impact of Magnesium Status on Stress Susceptibility}

Pre-clinical evidence. The relationship between magnesium deficiency and stress-related behavior is well documented. In 1986, Caddell et al. reported an increase of circulating catecholamines following the exposure of magnesium-deficient rats to a noise stress test [136]. The relationship between low serum magnesium concentrations and the increased release of catecholamines in the central nervous system was then confirmed in studies conducted on mice selected for low (MGL) and high (MGH) blood magnesium. The simple selection of genetic traits inducing low blood magnesium was found to significantly affect the metabolism of NA but not that of other neurotransmitters [137]. MGL mice not only showed higher NA levels (17\% in the brain; $200 \%$ in urine) but also a more restless behavior and higher rectal temperature, all signs of an exaggerated stress response [138]. In a different study also conducted on MGL and MGH mice, both fed with the same magnesium-rich diet, the number of stress-induced gastric ulcers through the immobilization test was higher in the magnesium-deficient mice [139]. Besides the noradrenergic hyperactivity in basal magnesium deficiency conditions, dietary magnesium restrictions have also been associated with an upregulation of the stress system via increases in CRH and ACTH levels [140]. Experimental data indicate that magnesium-deficient rats exhibit more anxiety- and depression-like behavior compared with controls [42,138]. For example, in the light-dark test (often used to screen for anxiolytic and antidepressant drugs) [141], mice with magnesium deficiency showed a net preference for the darker compartment $[42,140,141]$. Similarly, in the forced swimming test, magnesium-deficient rats spent more time immobile compared with their controls [142,143]. Dietary magnesium deficiency in laboratory animals was also associated with stress-like behavior in the open field test. Rats with a reduced dietary magnesium content tended to visit the bright and central area less frequently $[142,143]$, even when motivated by the presence of food, showing a psychological stress caused by the open space [140].

Clinical evidence. Results in human studies are consistent with animal findings and show low magnesium status in stressed/depressed populations. In a study investigating the potential benefit of magnesium supplementation in Russian women who suffered from chronic emotional stress, Akarachkova et al. found that at baseline the majority of women were suffering from symptoms like 
irritability, fatigue, and sleep disorders, and 60\% presented magnesium deficiency [144]. In other studies, subclinical chronic magnesium deficiency was found in up to $45 \%$ of the stressed subjects enrolled [78,145,146]. Nielsen et al. found that out of 96 American adults complaining of sleep disorders, a potential source of stress, 58\% were consuming less than the EAR for magnesium and had higher levels of C-reactive protein (CRP), an indicator of inflammatory stress [145]. Lastly, it is generally recognized that chronic stress and magnesium deficiency may influence an individual's susceptibility to depressive disorders [147]. In a group of Australian patients experiencing depression and/or anxiety, the analysis of their nutrition status showed that $22 \%$ of participants did not meet magnesium EAR. Furthermore, magnesium intake (expressed as \% EAR) was negatively correlated with stress, depression, and total Depression Anxiety Stress Scale (DASS) scores [148].

A summary of the pre-clinical and clinical evidence supporting a relation between magnesium status and stress is shown in Table 5.

Table 5. Summary of the pre-clinical and clinical evidence supporting magnesium status on stress susceptibility. ${ }^{\text {a }}$ Only symptoms shown in $\geq 70 \%$ of women at baseline are reported.

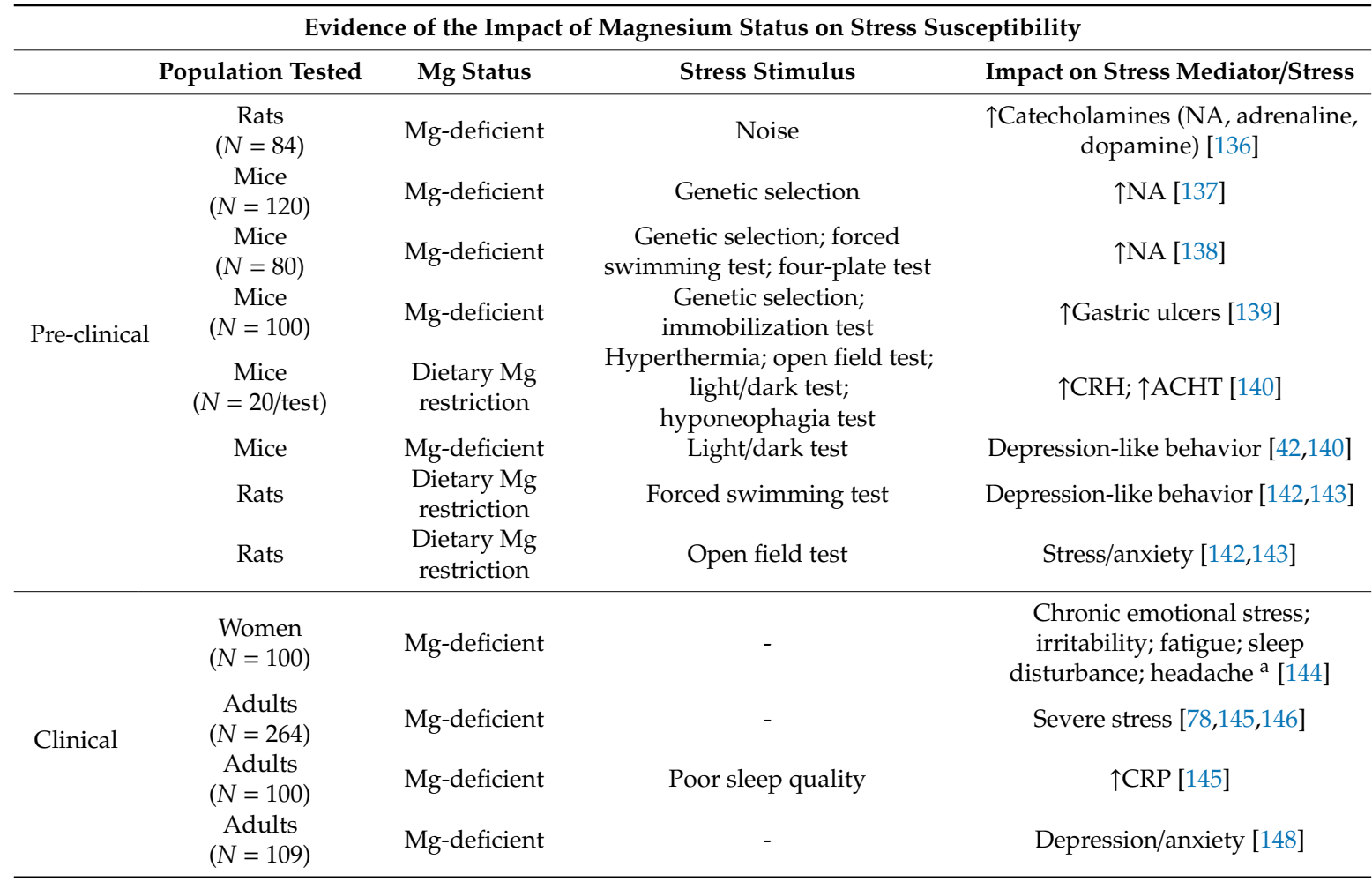

$\mathrm{ACHTH}$, adrenocorticotropic hormone; $\mathrm{CRH}$, corticotrophin-releasing hormone; CRP, C-reactive protein; $\mathrm{Mg}$, magnesium; NA, noradrenaline; $\uparrow$, increase.

\section{Proposed Model for the Vicious Circle of Stress and Magnesium Deficiency}

Over the years, a growing body of evidence has consistently shown that magnesium acts on several key physiological steps involved in the response to stressful stimuli.

- Magnesium and HPA. 5-HT transmission: Magnesium directly enhances the interaction between 5-HT and its membrane receptor, and it promotes the cellular transmission of the serotoninergic signal (Figure 2A) [90]. Additionally, magnesium is a cofactor of tryptophan hydroxylase, the enzyme involved in 5-HT synthesis [90]. Glutamatergic transmission: Magnesium inhibits the glutamate directly and indirectly by blocking the glutamate N-methyl-D-aspartate (NMDA) receptor and by enhancing its reuptake in the synaptic vesicles through stimulation of the sodium-potassium ATPase, respectively (Figure 2B) [42]. GABA transmission: A GABA-agonistic activity of magnesium has been observed, although the mechanism has not yet been elucidated, 
(Figure 2B) [42]. Cortisol: Magnesium indirectly reduces the release of ACTH by modulating the neurotransmission pathways, and therefore decreases cortisol levels in the body [42];

- Magnesium and neuroprotection. Studies on the antidepressant effects of magnesium have shown the positive impact of this mineral on the expression of BNDF in the brain [149,150];

- Magnesium and oxidative stress. Magnesium may be involved in suppressing the production of free radicals in various tissues including the brain [17], and several laboratory studies have shown that magnesium-deficient animals are more at risk of oxidative stress [112,151].

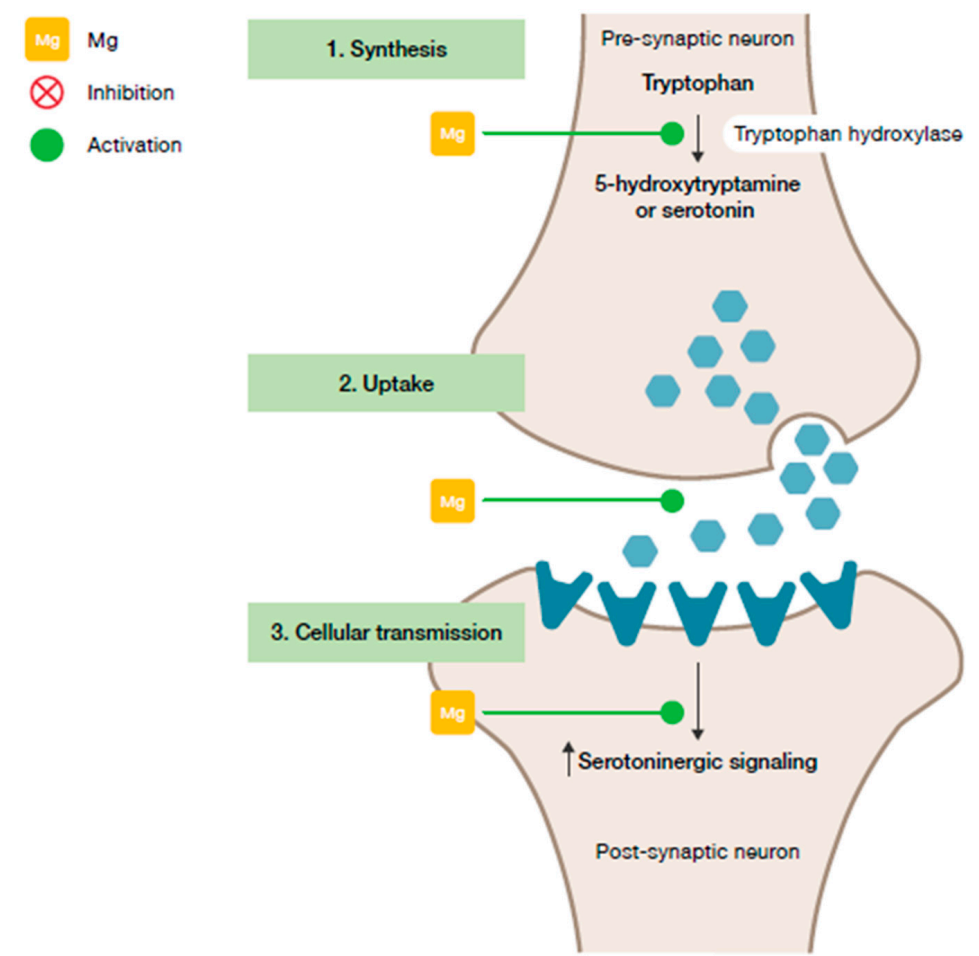

(A)

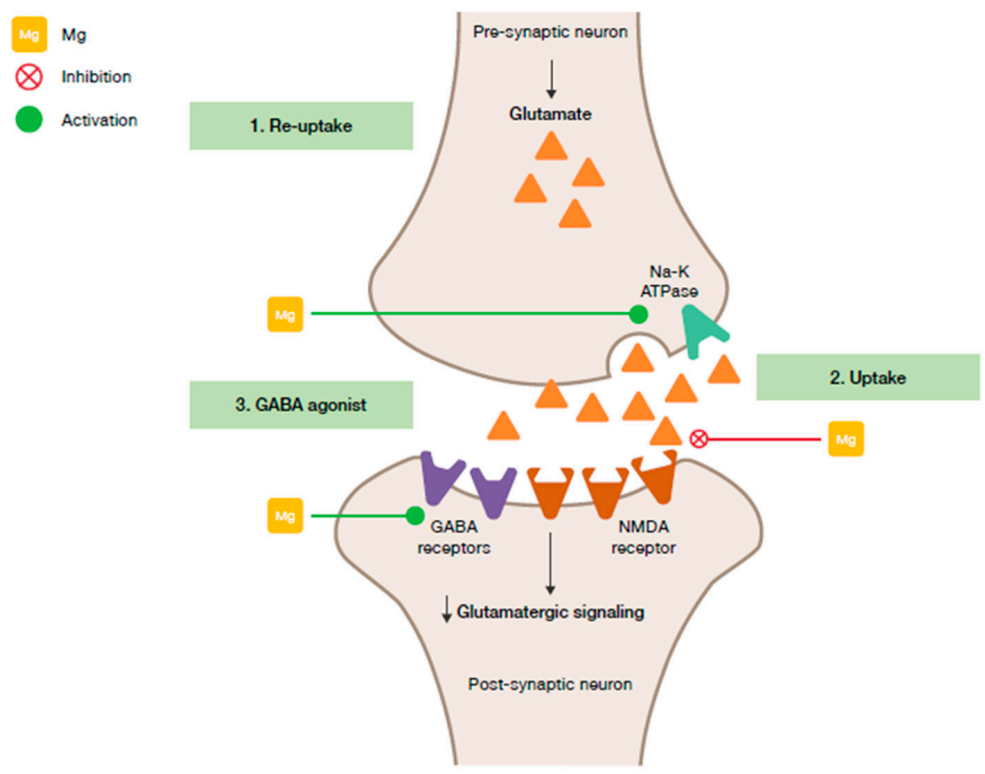

(B)

Figure 2. Interaction of magnesium and neurological stress mediators. (A) Serotoninergic transmission. (B) Glutamatergic and GABAergic transmission. GABA, $\gamma$-aminobutyric acid; $\mathrm{Mg}$, magnesium; NMDA, N-methyl-D-aspartate. 
In response to a stressful stimulus, stress hormones are released, causing an increase of magnesium extracellular levels [90]. As a consequence, higher magnesium concentrations are excreted through the kidneys [133]. When the stressor persists over time, this mechanism may contribute to magnesium cation depletion and deficiency $[42,130]$, and trigger the stress and magnesium vicious circle as illustrated in Figure 3.

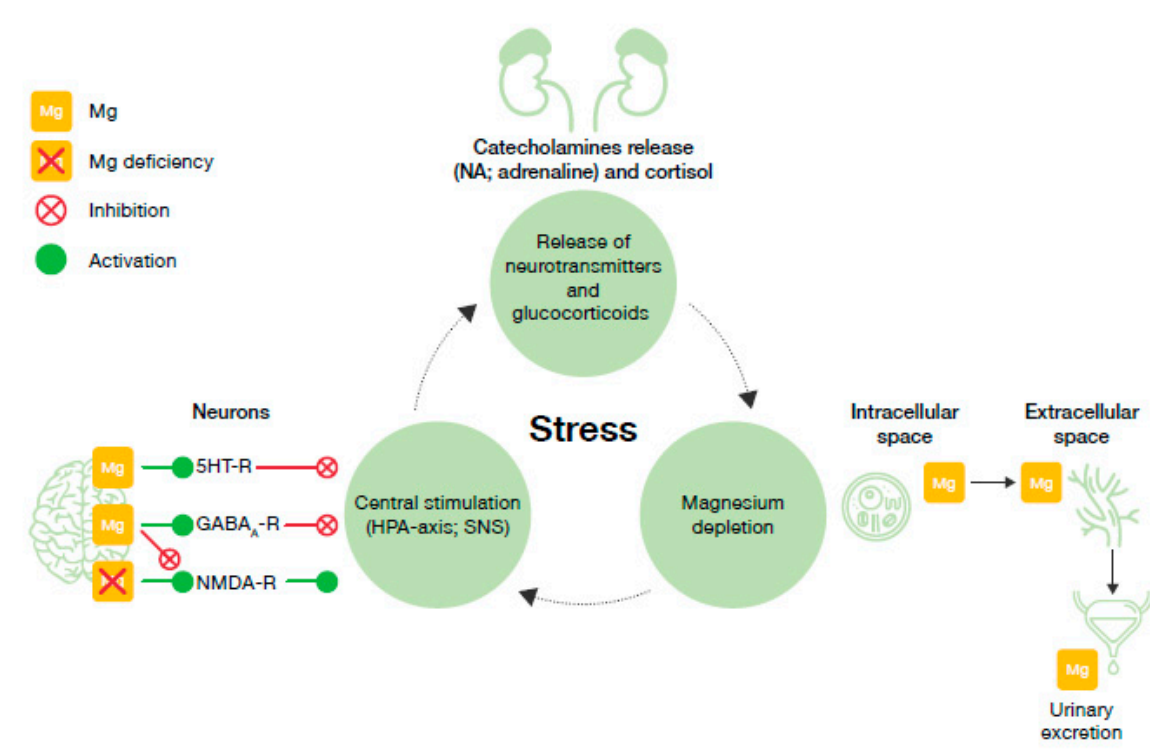

Figure 3. The vicious circle of stress and magnesium. GABAA-R, $\gamma$-aminobutyric acid-A receptor; $\mathrm{Mg}$, magnesium; NMDA-R, N-methyl-D-aspartate receptor; NA, noradrenaline; SNS, sympathetic nervous system, 5HT-R, 5-hydroxytryptamine receptor.

Comprehensively, both pre-clinical and clinical studies' results point to the bi-directional relationship between magnesium levels and stress: Magnesium deficiency can induce symptoms and increase susceptibility to stress, and acute and chronic stress can precipitate magnesium deficiency $[10,104,106]$.

\section{Magnesium Supplementation}

Magnesium supplementation has proven benefits for the treatment of symptoms of psychological daily stress (fatigue, irritability, sleep) [144]. It has been shown that subjects with mental and physical stress can benefit from a daily intake of magnesium. Male students experiencing common stress factors such as sleep deprivation, malnutrition, and a lack of physical activity, and receiving magnesium $250 \mathrm{mg} /$ day for four weeks not only presented an increase in erythrocyte magnesium content but also a reduction of serum cortisol [152]. Magnesium supplementation of $400 \mathrm{mg} /$ day was associated with a clear improvement of the heart rate variability, measured as an indicator of the parasympathetic and vagal systems' response to stress, in subjects who were asked to complete moderate muscle endurance training once weekly [153]. The daily supplementation with $300 \mathrm{mg}$ (combined or not with vitamin B6, $30 \mathrm{mg}$ ) provided positive results on stress relief [154], particularly on subjects who reported severe stress levels at baseline, with a reduction in Depression Anxiety Stress Scale scores of up to $45 \%$ from baseline [154]. It is interesting to note that several studies investigating the potential benefit of magnesium supplementation in populations with symptoms of stress reported a subclinical chronic magnesium deficiency or a low magnesium status at baseline in the majority of the subjects enrolled $[37,78,144-146]$. Nevertheless, despite several studies reporting an association between magnesium deficiency and stress, the effect of magnesium supplementation on stress has been less documented than its effects on depression [37,155] and anxiety disorders [156]; therefore, further investigation is still needed on stress symptoms. A possible limiting factor to the performance 
of such studies could be the difficulty of setting up optimal experimental conditions for studying the effect of stress; however, this challenge may be overcome in future analyses by focusing on well-defined conditions (e.g., psychological stress), and by using robust and validated tools to assess stress (such as DASS scores).

\section{Conclusions: Implications in Terms of Dietary Magnesium Needs}

Over the past decades, increasing evidence, as shown in the present narrative review, has investigated and supported the link between magnesium deficiency and increased susceptibility to stress disorders, and further suggested that stress itself can lead to magnesium depletion. Magnesium is an essential element involved in reactions regulating the body's stress response at several levels. Severe magnesium deficiency is rare, but chronic latent deficiency appears to be common among the general population and even more among those suffering from a number of chronic diseases or stress [5]. Although the current intake of magnesium through our diet seems sufficient to avoid overt signs of magnesium deficiency in the majority of the population, it might not be adequate to provide optimal health and risk reduction of chronic diseases [5]. Stress is also an increasing condition worldwide and its effects can negatively impact health outcomes. Noteworthy, magnesium intake has been found negatively correlated with subjective stress in some populations [148], and magnesium supplementation has shown benefits in stressed but otherwise healthy subjects [153,154]. Additionally, magnesium intake is safe with limited side-effects in cases of chronic overconsumption [72].

To conclude, while there is good evidence from animal and human studies of the bi-directional link between magnesium and stress, further research is needed to better understand the impact of this correlation and the benefit of magnesium supplementation on general health. Additional studies should apply standard methodologies (e.g., magnesium load test) to evaluate the magnesium status in well-characterized stressed population. These studies would help to demonstrate the increased need of magnesium supplementation during stress periods, and further strengthen our initial hypothesis. Further, in line with the GUTS model, repetitive negative thinking could be considered as a cognitive indicator of stress and evaluated in relation to blood magnesium levels in a cohort of subjects exposed to chronic stress. Given the strong association of stress with mental and physical diseases, these studies are fundamental to further support adequate magnesium dietary needs.

Author Contributions: Conceptualization, M.A., L.N.; writing—original draft preparation, and writing-review and editing, G.P., A.M., M.T., P.B., N.Y., M.A., L.N., E.P.; supervision, project administration, funding acquisition, A.M., L.N. All authors have read and agreed to the published version of the manuscript.

Funding: This review was funded by Sanofi.

Acknowledgments: Editorial support was provided by Martina Klinger Sikora and Mark Davies of inScience Communications, Springer Healthcare Ltd., UK.

Conflicts of Interest: A.M. reports consultancy fees from Sanofi, unrelated to this publication. E.P. is an employee at Sanofi. G.P. has no conflicts of interest. L.N. is an employee at Sanofi. M.A. is an employee at Sanofi. M.T. has no conflicts of interest. P.B. reports speaker's honoraria from: Abbott, Adamed, Angelini, Apotex, Astellas, Asteriamed, Bausch Health, BGP Products, BMS, Bioton, Boehringer Ingelheim, Bonnier Business, Chiesi, CROS, Fundacja Syntonia, Fundacja Zdrowie i Opieka, Gedeon Richter, + pharma, G-Pharma, Ipsen, Item Publishing, Janssen, Kimze, Krka, Lilly, Lundbeck, Medforum, Mediadore, Medical Education, Medical Experts, Medycyna Praktyczna, Mylan, Neoart, Novo Nordisk, P2P, Pfizer, Pierre Fabre, Polfa Tarchomin, Polpharma, Promed, QAH, Sandoz, Sanofi-Aventis, Servier, S \& P Partners, Takeda, Termedia, Teva, Warsaw Voice, White Solutions, Valeant, Via Medica, VM Media, Zentiva. Y.N. has no conflicts of interest.

\section{References}

1. Kessler, R.C.; Aguilar-Gaxiola, S.; Alonso, J.; Chatterji, S.; Lee, S.; Ormel, J.; Üstün, T.B.; Wang, P.S. The global burden of mental disorders: An update from the WHO World Mental Health (WMH) Surveys. Epidemiol. Psichiatr. Soc. 2009, 18, 23-33. [CrossRef] [PubMed]

2. McEwen, B.S.; Akil, H. Revisiting the Stress Concept: Implications for Affective Disorders. J. Neurosci. 2020, 40, 12-21. [CrossRef] [PubMed] 
3. Konrad, M.; Schlingmann, K.P.; Gudermann, T. Insights into the molecular nature of magnesium homeostasis. Am. J. Physiol. Renal. Physiol. 2004, 286, F599-F605. [CrossRef] [PubMed]

4. Pham, P.C.; Pham, P.M.; Pham, S.V.; Miller, J.M.; Pham, P.T. Hypomagnesemia in patients with type 2 diabetes. Clin. J. Am. Soc. Nephrol. 2007, 2, 366-373. [CrossRef]

5. DiNicolantonio, J.J.; O'Keefe, J.H.; Wilson, W. Subclinical magnesium deficiency: A principal driver of cardiovascular disease and a public health crisis. Open Heart 2018, 5, e000668. [CrossRef]

6. American Psychological Association. Stress Effects on the Body. Available online: https://www.apa.org/ helpcenter/stress (accessed on 30 June 2020).

7. American Psychological Association. Understanding Chronic Stress. Available online: https://www.apa.org/ helpcenter/understanding-chronic-stress.aspx (accessed on 30 June 2020).

8. De Baaij, J.H.; Hoenderop, J.G.; Bindels, R.J. Magnesium in man: Implications for health and disease. Physiol. Rev. 2015, 95, 1-46. [CrossRef]

9. Galland, L. Magnesium, stress and neuropsychiatric disorders. Magnes. Trace Elem. 1991, 10, $287-301$.

10. Seelig, M.S. Consequences of magnesium deficiency on the enhancement of stress reactions; preventive and therapeutic implications (a review). J. Am. Coll. Nutr. 1994, 13, 429-446. [CrossRef]

11. American Psychological Association. 2015 Stress in America. Available online: https://www.apa.org/news/ press/releases/stress/2015/snapshot (accessed on 10 August 2020).

12. Costello, R.; Wallace, T.C.; Rosanoff, A. Magnesium. Adv. Nutr. 2016, 7, 199-201. [CrossRef]

13. Reddy, S.T.; Soman, S.S.; Yee, J. Magnesium Balance and Measurement. Adv. Chronic Kidney Dis. 2018, 25, $224-229$. [CrossRef] [PubMed]

14. Glasdam, S.M.; Glasdam, S.; Peters, G.H. The Importance of Magnesium in the Human Body: A Systematic Literature Review. Adv. Clin. Chem. 2016, 73, 169-193. [CrossRef] [PubMed]

15. Bergman, C.; Gray-Scott, D.; Chen, J.J.; Meacham, S. What is next for the Dietary Reference Intakes for bone metabolism related nutrients beyond calcium: Phosphorus, magnesium, vitamin D, and fluoride? Crit Rev Food Sci. Nutr. 2009, 49, 136-144. [CrossRef] [PubMed]

16. EFSA Panel on Dietetic Products Nutrition and Allergies (NDA). Scientific Opinion on Dietary Reference Values for magnesium. EFSA J. 2015, 13, 4186. [CrossRef]

17. Yamanaka, R.; Shindo, Y.; Oka, K. Magnesium Is a Key Player in Neuronal Maturation and Neuropathology. Int. J. Mol. Sci. 2019, 20, 3439. [CrossRef] [PubMed]

18. Ghabriel, M.N.; Vink, R. Magnesium transport across the blood-brain barriers. In Magnesium in the Central Nervous System; Nechifor, M., Vink, R., Eds.; The University of Adelaide Press: Adelaide, Australia, 2011; pp. 59-74. [CrossRef]

19. Morris, M.E. Brain and CSF magnesium concentrations during magnesium deficit in animals and humans: Neurological symptoms. Magnes. Res. 1992, 5, 303-313. [PubMed]

20. Chutkow, J.G. Uptake of magnesium into the brain of the rat. Exp. Neurol. 1978, 60, 592-602. [CrossRef]

21. Jahnen-Dechent, W.; Ketteler, M. Magnesium basics. Clin. Kidney J. 2012, 5, i3-i14. [CrossRef]

22. Ross, C.A.; Caballero, B.; Cousins, R.J.; Tucker, K.L.; Ziegler, T.R. Modern Nutrition in Health and Disease, 11th ed.; Lippincott Williams \& Wilkins: Baltimore, MD, USA, 2014; pp. 159-175.

23. Clarkson, E.M.; Warren, R.L.; McDonald, S.J.; de Wardener, H.E. The effect of a high intake of calcium on magnesium metabolism in normal subjects and patients with chronic renal failure. Clin. Sci. 1967, 32, 11-18.

24. Norman, D.A.; Fordtran, J.S.; Brinkley, L.J.; Zerwekh, J.E.; Nicar, M.J.; Strowig, S.M.; Pak, C.Y. Jejunal and ileal adaptation to alterations in dietary calcium: Changes in calcium and magnesium absorption and pathogenetic role of parathyroid hormone and 1,25-dihydroxyvitamin D. J. Clin. Investig. 1981, 67, 1599-1603. [CrossRef]

25. Johnson, S. The multifaceted and widespread pathology of magnesium deficiency. Med. Hypotheses 2001, 56, 163-170. [CrossRef]

26. Ayuk, J.; Gittoes, N.J. Contemporary view of the clinical relevance of magnesium homeostasis. Ann. Clin. Biochem. 2014, 51, 179-188. [CrossRef] [PubMed]

27. Gröber, U. Magnesium and Drugs. Int. J. Mol. Sci. 2019, 20, 2094. [CrossRef] [PubMed]

28. Dalton, L.M.; DM, N.F.; Gaydadzhieva, G.T.; Mazurkiewicz, O.M.; Leeson, H.; Wright, C.P. Magnesium in pregnancy. Nutr. Rev. 2016, 74, 549-557. [CrossRef] [PubMed]

29. Morton, A. Hypomagnesaemia and pregnancy. Obstet. Med. 2018, 11, 67-72. [CrossRef] [PubMed] 
30. Parazzini, F.; Di Martino, M.; Pellegrino, P. Magnesium in the gynecological practice: A literature review. Magnes. Res. 2017, 30,1-7. [CrossRef]

31. Seelig, M.S.; Preuss, H.G. Magnesium metabolism and perturbations in the elderly. Geriatr. Nephrol. Urol. 1994, 4, 101-111. [CrossRef]

32. Lo Piano, F.; Corsonello, A.; Corica, F. Magnesium and elderly patient: The explored paths and the ones to be explored: A review. Magnes. Res. 2019, 32,1-15. [CrossRef]

33. Swaminathan, R. Magnesium metabolism and its disorders. Clin. Biochem. Rev. 2003, 24, 47-66.

34. Guerrero-Romero, F.; Rodríguez-Morán, M. Low serum magnesium levels and metabolic syndrome. Acta Diabetol. 2002, 39, 209-213. [CrossRef]

35. Viering, D.H.H.M.; de Baaij, J.H.F.; Walsh, S.B.; Kleta, R.; Bockenhauer, D. Genetic causes of hypomagnesemia, a clinical overview. Pediatr. Nephrol. 2017, 32, 1123-1135. [CrossRef]

36. Naderi, A.S.A.; Reilly, R.F. Hereditary etiologies of hypomagnesemia. Nat. Clin. Pract. Nephrol. 2008, 4, 80-89. [CrossRef] [PubMed]

37. Botturi, A.; Ciappolino, V.; Delvecchio, G.; Boscutti, A.; Viscardi, B.; Brambilla, P. The Role and the Effect of Magnesium in Mental Disorders: A Systematic Review. Nutrients 2020, 12, 1661. [CrossRef] [PubMed]

38. Nielsen, F.H.; Lukaski, H.C. Update on the relationship between magnesium and exercise. Magnes. Res. 2006, 19, 180-189. [PubMed]

39. Laires, M.J.; Monteiro, C. Exercise and Magnesium. In New Perspectives in Magnesium Research: Nutrition and Health; Nishizawa, Y., Morii, H., Durlach, J., Eds.; Springer: London, UK, 2007; pp. 173-185. [CrossRef]

40. Warburton, D.E.R.; Welsh, R.C.; Haykowsky, M.J.; Taylor, D.A.; Humen, D.P. Biochemical changes as a result of prolonged strenuous exercise. Br. J. Sports Med. 2002, 36, 301. [CrossRef]

41. Ikonte, C.J.; Mun, J.G.; Reider, C.A.; Grant, R.W.; Mitmesser, S.H. Micronutrient Inadequacy in Short Sleep: Analysis of the NHANES 2005-2016. Nutrients 2019, 11, 2335. [CrossRef]

42. Murck, H. Magnesium and affective disorders. Nutr. Neurosci. 2002, 5, 375-389. [CrossRef]

43. Cernak, I.; Savic, V.; Kotur, J.; Prokic, V.; Kuljic, B.; Grbovic, D.; Veljovic, M. Alterations in magnesium and oxidative status during chronic emotional stress. Magnes. Res. 2000, 13, $29-36$.

44. Grases, G.; Pérez-Castelló, J.A.; Sanchis, P.; Casero, A.; Perelló, J.; Isern, B.; Rigo, E.; Grases, F. Anxiety and stress among science students. Study of calcium and magnesium alterations. Magnes. Res. 2006, 19, $102-106$.

45. Classen, H.G. Systemic stress, magnesium status and cardiovascular damage. Magnesium 1986, 5, $105-110$.

46. United States Department of Health and Human Services. Scientific Report of the 2015 Dietary Guidelines Advisory Committee-Advisory Report to the Secretary of Health and Human Services and the Secretary of Agriculture; USDA Agricoltural Research Service: Washngton, DC, USA, 2015.

47. Agence Nationale de Sécurité Sanitaire de L'alimentation de L'environnement et du Travail (ANSES). TANSES-CIQUAL French Food Composition Table, Version 2017; ANSES: Maisons-Alfort, France, 2017.

48. Costello, R.B.; Elin, R.J.; Rosanoff, A.; Wallace, T.C.; Guerrero-Romero, F.; Hruby, A.; Lutsey, P.L.; Nielsen, F.H.; Rodriguez-Moran, M.; Song, Y.; et al. Perspective: The Case for an Evidence-Based Reference Interval for Serum Magnesium: The Time Has Come. Adv. Nutr. 2016, 7, 977-993. [CrossRef]

49. Ford, E.S.; Mokdad, A.H. Dietary Magnesium Intake in a National Sample of U.S. Adults. J. Nutr. 2003, 133, 2879-2882. [CrossRef] [PubMed]

50. Winiarska-Mieczan, A.; Zaricka, E.; Kwiecień, M.; Kwiatkowska, K.; Baranowska-Wójcik, E.; Danek-Majewska, A. Can Cereal Products Be an Essential Source of Ca, Mg and $\mathrm{K}$ in the Deficient Diets of Poles? Biol. Trace Elem. Res. 2020, 195, 317-322. [CrossRef] [PubMed]

51. Górska-Warsewicz, H.; Rejman, K.; Laskowski, W.; Czeczotko, M. Milk and Dairy Products and Their Nutritional Contribution to the Average Polish Diet. Nutrients 2019, 11, 1771. [CrossRef] [PubMed]

52. Lombardi-Boccia, G.; Aguzzi, A.; Cappelloni, M.; Di Lullo, G.; Lucarini, M. Total-diet study: Dietary intakes of macro elements and trace elements in Italy. Br. J. Nutr. 2003, 90, 1117-1121. [CrossRef] [PubMed]

53. Nielsen, F.H. The Problematic Use of Dietary Reference Intakes to Assess Magnesium Status and Clinical Importance. Biol. Trace Elem. Res. 2019, 188, 52-59. [CrossRef] [PubMed]

54. Dong, J.Y.; Xun, P.; He, K.; Qin, L.Q. Magnesium intake and risk of type 2 diabetes: Meta-analysis of prospective cohort studies. Diabetes Care 2011, 34, 2116-2122. [CrossRef] [PubMed]

55. Schwartz, R.; Apgar, B.J.; Wien, E.M. Apparent absorption and retention of $\mathrm{Ca}, \mathrm{Cu}, \mathrm{Mg}, \mathrm{Mn}$, and $\mathrm{Zn}$ from a diet containing bran. Am. J. Clin. Nutr. 1986, 43, 444-455. [CrossRef] 
56. Lakshmanan, F.L.; Rao, R.B.; Kim, W.W.; Kelsay, J.L. Magnesium intakes, balances, and blood levels of adults consuming self-selected diets. Am. J. Clin. Nutr. 1984, 40, 1380-1389. [CrossRef]

57. Greger, J.L.; Baier, M.J. Effect of dietary aluminum on mineral metabolism of adult males. Dev. Med. Child Neurol. 1983, 38, 411-419. [CrossRef]

58. Standing Commitee on the Scientific Evaluation of Dietary Reference Intakes Institute of Medicine. Dietary reference intakes for calcium, phosphorus, magnesium, vitamin D, and fluoride. In Dietary Reference Intakes for Calcium, Phosphorus, Magnesium, Vitamin D, and Fluoride; National Acedemies Press, Ed.; The National Academies Press: Washington, DC, USA, 1997; pp. 190-249.

59. Jarosz, M. Nutritional Guidelines for the Polish Population; National Food and Nutrition Institute, Ed.; National Food and Nutrition Institute: Warsaw, Poland, 2017.

60. Tutel'ian, V.A. Norms of physiological requirements in energy and nutrients in various groups of population in Russian Federation. Vopr. Pitan. 2009, 78, 4-15.

61. Ministry of Health Labour and Welfare. Dietary Reference Intakes for Japanese; Japan Government Printing Office, Ed.; Ministry of Health Labour and Welfare: Tokyo, Japan, 2015.

62. Società Italiana di Nutrizione Umana-SINU. LARN_Livelli di Assunzione di Riferimento per la Popolazione Italiana: MINERALI. Assunzione Raccomandata per la Popolazione (PRI in Grassetto) e Assunzione Adeguata (AI in Corsivo): Valori su Base Giornaliera. Available online: https://sinu.it/2019/07/09/mineraliassunzione-raccomandata-per-la-popolazione-pri-e-assunzione-adeguataai/ (accessed on 30 June 2020).

63. Agence Nationale de Sécurité Sanitaire de L'alimentation de L'environnement et du Travail (ANSES). Avis de l'ANSES. In Actualisation des Repères du PNNS: Élaborationdes Références Nutritionnelles; ANSES, Ed.; ANSES: Maisons-Alfort, France, 2016.

64. Vormann, J. Magnesium: Nutrition and metabolism. Mol. Asp. Med. 2003, 24, 27-37. [CrossRef]

65. King, D.E.; Mainous, A.G., 3rd; Geesey, M.E.; Woolson, R.F. Dietary magnesium and C-reactive protein levels. J. Am. Coll. Nutr. 2005, 24, 166-171. [CrossRef] [PubMed]

66. Bailey, R.L.; Fulgoni, V.L., 3rd; Keast, D.R.; Dwyer, J.T. Dietary supplement use is associated with higher intakes of minerals from food sources. Am. J. Clin. Nutr. 2011, 94, 1376-1381. [CrossRef] [PubMed]

67. Public Health England. Official Statistics NDNS: Results from Years 7 and 8 (Combined). Results of the National Diet and Nutrition Survey (NDNS) Rolling Programme for 2014 to 2015 and 2015 to 2016; Public Health England: England, UK, 2018.

68. Agence Nationale de Sécurité Sanitaire de L'alimentation de L'environnement et du Travail (ANSES). Avis de l'ANSES relatif à l'évaluation des apports en vitamines et minéraux issus de l'alimentation non enrichie, de l'alimentation enrichie et des compléments alimentaires dans la population Française: estimation des aApports usuels, des prévalences d'inadéquation et des risques de dépassement des limites de sécurité(Saisine n²012-SA-0142); ANSES, Ed.; ANSES: Maisons-Alfort, France, 2015.

69. Olza, J.; Aranceta-Bartrina, J.; González-Gross, M.; Ortega, R.M.; Serra-Majem, L.; Varela-Moreiras, G.; Gil, Á. Reported Dietary Intake, Disparity between the Reported Consumption and the Level Needed for Adequacy and Food Sources of Calcium, Phosphorus, Magnesium and Vitamin D in the Spanish Population: Findings from the ANIBES Study. Nutrients 2017, 9, 168. [CrossRef]

70. Castiglione, D.; Platania, A.; Conti, A.; Falla, M.; D’Urso, M.; Marranzano, M. Dietary Micronutrient and Mineral Intake in the Mediterranean Healthy Eating, Ageing, and Lifestyle (MEAL) Study. Antioxidants 2018, 7, 79. [CrossRef]

71. Mensink, G.B.; Fletcher, R.; Gurinovic, M.; Huybrechts, I.; Lafay, L.; Serra-Majem, L.; Szponar, L.; Tetens, I.; Verkaik-Kloosterman, J.; Baka, A.; et al. Mapping low intake of micronutrients across Europe. Br. J. Nutr. 2013, 110, 755-773. [CrossRef]

72. National Institute of Health, Office of Dietary Supplements. Magnesium. Available online: https://ods.od. nih.gov/factsheets/Magnesium-HealthProfessional/\#en1 (accessed on 10 August 2020).

73. Institute of Medicine. Dietary Reference Intakes for Calcium, Phosphorus, Magnesium, Vitamin D, and Fluoride; The National Academies Press: Washington, DC, USA, 1997; p. 448. [CrossRef]

74. Spätling, L.; Classen, H.G.; Külpmann, W.R.; Manz, F.; Rob, P.M.; Schimatschek, H.F.; Vierling, W.; Vormann, J.; Weigert, A.; Wink, K. Diagnosing magnesium deficiency. Current recommendations of the Society for Magnesium Research. Fortschr. Med. Orig. 2000, 118 (Suppl. 2), 49-53.

75. Lowenstein, F.W.; Stanton, M.F. Serum magnesium levels in the United States, 1971-1974. J. Am. Coll. Nutr. 1986, 5, 399-414. [CrossRef] 
76. Topf, J.M.; Murray, P.T. Hypomagnesemia and hypermagnesemia. Rev. Endocr. Metab. Disord. 2003, 4, $195-206$. [CrossRef]

77. Elin, R.J. Assessment of magnesium status for diagnosis and therapy. Magnes. Res. 2010, 23, S194-S198. [CrossRef]

78. Noah, L.; Pickering, G.; Mazur, A.; Dubray, C.; Hitier, S.; Dualé, C.; Pouteau, E. Impact of magnesium supplementation, in combination with vitamin B6, on stress and magnesium status: Secondary data from a randomised controlled trial. Magnes. Res. J. 2020, 33, 45-57.

79. Rosanoff, A.; Weaver, C.M.; Rude, R.K. Suboptimal magnesium status in the United States: Are the health consequences underestimated? Nutr. Rev. 2012, 70, 153-164. [CrossRef] [PubMed]

80. Meyer, T.E.; Verwoert, G.C.; Hwang, S.J.; Glazer, N.L.; Smith, A.V.; van Rooij, F.J.; Ehret, G.B.; Boerwinkle, E.; Felix, J.F.; Leak, T.S.; et al. Genome-wide association studies of serum magnesium, potassium, and sodium concentrations identify six Loci influencing serum magnesium levels. PLoS Genet. 2010, 6, e1001045. [CrossRef] [PubMed]

81. Moshfegh, A.; Goldman, J.; Ahuja, J.; Rhodes, D.; LaComb, R. What We Eat in America, NHANES 2005-2006. Usual Nutrient Intakes from Food and Water Compared to 1997 Dietary Reference Intakes for Vitamid D, Calcium, Phosphorus, and Magnesium; United States Department of Agriculture, Agricultural Research Service, Eds.; 2009. Available online: https://www.ars.usda.gov/ARSUserFiles/80400530/pdf/0506/usual_nutrient_intake_ vitD_ca_phos_mg_2005-06.pdf (accessed on 30 June 2020).

82. Guo, W.; Nazim, H.; Liang, Z.; Yang, D. Magnesium deficiency in plants: An urgent problem. Crop J. 2016, 4, 83-91. [CrossRef]

83. Cakmak, I. Magnesium in crop production, food quality and human health. Plant Soil 2013, 368, 1-4. [CrossRef]

84. Workinger, J.L.; Doyle, R.P.; Bortz, J. Challenges in the Diagnosis of Magnesium Status. Nutrients 2018, 10, 1202. [CrossRef]

85. Worthington, V. Nutritional quality of organic versus conventional fruits, vegetables, and grains. J. Altern. Complement. Med. 2001, 7, 161-173. [CrossRef]

86. Thomas, D. The mineral depletion of foods available to us as a nation (1940-2002) -A Review of the 6th Edition of McCance and Widdowson. Nutr. Health 2007, 19, 21-55. [CrossRef]

87. Du, J.; Zhu, M.; Bao, H.; Li, B.; Dong, Y.; Xiao, C.; Zhang, G.Y.; Henter, I.; Rudorfer, M.; Vitiello, B. The Role of Nutrients in Protecting Mitochondrial Function and Neurotransmitter Signaling: Implications for the Treatment of Depression, PTSD, and Suicidal Behaviors. Crit. Rev. Food Sci. Nutr. 2016, 56, 2560-2578. [CrossRef]

88. Fromm, L.; Heath, D.L.; Vink, R.; Nimmo, A.J. Magnesium Attenuates Post-Traumatic Depression/Anxiety Following Diffuse Traumatic Brain Injury in Rats. J. Am. Coll. Nutr. 2004, 23, 529S-533S. [CrossRef]

89. Veronese, N.; Solmi, M. Impaired Magnesium Status and Depression. In Handbook of Famine, Starvation, and Nutrient Deprivation: From Biology to Policy; Preedy, V.R., Patel, V.B., Eds.; Springer: Berlin/Heidelberg, Germany, 2019; pp. 1861-1872. [CrossRef]

90. Cuciureanu, M.; Vink, R. Magnesium and stress. In Magnesium in the Central Nervous System; Vink, R., Nechifor, M., Eds.; University of Adelaide Press: Adelaide, Australia, 2011.

91. Chrousos, G.P. Stress and disorders of the stress system. Nat. Rev. Endocrinol. 2009, 5, 374-381. [CrossRef] [PubMed]

92. Yaribeygi, H.; Panahi, Y.; Sahraei, H.; Johnston, T.P.; Sahebkar, A. The impact of stress on body function: A review. EXCLI J. 2017, 16, 1057-1072. [CrossRef] [PubMed]

93. Selye, H. Stress and the general adaptation syndrome. Br. Med. J. 1950, 1, 1383-1392. [CrossRef] [PubMed]

94. Clark, M.S.; Bond, M.J.; Hecker, J.R. Environmental stress, psychological stress and allostatic load. Psychol. Health Med. 2007, 12, 18-30. [CrossRef] [PubMed]

95. McEwen, B.S. Protective and damaging effects of stress mediators. N. Engl. J. Med. 1998, 338, 171-179. [CrossRef]

96. McEwen, B.S. Protection and damage from acute and chronic stress: Allostasis and allostatic overload and relevance to the pathophysiology of psychiatric disorders. Ann. N. Y. Acad Sci 2004, 1032, 1-7. [CrossRef]

97. Carrasco, G.A.; Van de Kar, L.D. Neuroendocrine pharmacology of stress. Eur. J. Pharm. 2003, 463, $235-272$. [CrossRef] 
98. Lanfumey, L.; Mongeau, R.; Cohen-Salmon, C.; Hamon, M. Corticosteroid-serotonin interactions in the neurobiological mechanisms of stress-related disorders. Neurosci. Biobehav. Rev. 2008, 32, 1174-1184. [CrossRef]

99. Herman, J.P.; Mueller, N.K.; Figueiredo, H. Role of GABA and glutamate circuitry in hypothalamopituitary-adrenocortical stress integration. Ann. N. Y. Acad. Sci. 2004, 1018, 35-45. [CrossRef]

100. Nakamura, J.; Yakata, M. Two-cycle liquid-chromatographic quantitation of cortisol in urine. Clin. Chem. 1982, 28, 1497-1500. [CrossRef]

101. Singh, A.; Petrides, J.S.; Gold, P.W.; Chrousos, G.P.; Deuster, P.A. Differential hypothalamic-pituitary-adrenal axis reactivity to psychological and physical stress. J. Clin. Endocrinol. Metab. 1999, 84, 1944-1948. [CrossRef] [PubMed]

102. Ullmann, E.; Perry, S.W.; Licinio, J.; Wong, M.-L.; Dremencov, E.; Zavjalov, E.L.; Shevelev, O.B.; Khotskin, N.V.; Koncevaya, G.V.; Khotshkina, A.S.; et al. From Allostatic Load to Allostatic State-An Endogenous Sympathetic Strategy to Deal With Chronic Anxiety and Stress? Front. Behav. Neurosci. 2019, 13. [CrossRef] [PubMed]

103. de Assis, G.G.; Gasanov, E.V. BDNF and Cortisol integrative system-Plasticity vs. degeneration: Implications of the Val66Met polymorphism. Front. Neuroendocrinol. 2019, 55. [CrossRef] [PubMed]

104. Karatsoreos, I.N.; McEwen, B.S. Psychobiological allostasis: Resistance, resilience and vulnerability. Trends Cogn. Sci. 2011, 15, 576-584. [CrossRef]

105. Wallingford, J.K.; Deurveilher, S.; Currie, R.W.; Fawcett, J.P.; Semba, K. Increases in mature brain-derived neurotrophic factor protein in the frontal cortex and basal forebrain during chronic sleep restriction in rats: Possible role in initiating allostatic adaptation. Neuroscience 2014, 277, 174-183. [CrossRef]

106. Yuluğ, B.; Ozan, E.; Gönül, A.S.; Kilic, E. Brain-derived neurotrophic factor, stress and depression: A minireview. Brain Res. Bull. 2009, 78, 267-269. [CrossRef]

107. Colaianna, M.; Schiavone, S.; Zotti, M.; Tucci, P.; Morgese, M.G.; Bäckdahl, L.; Holmdahl, R.; Krause, K.-H.; Cuomo, V.; Trabace, L. Neuroendocrine profile in a rat model of psychosocial stress: Relation to oxidative stress. Antioxid. Redox. Signal 2013, 18, 1385-1399. [CrossRef]

108. Kapczinski, F.; Vieta, E.; Andreazza, A.C.; Frey, B.N.; Gomes, F.A.; Tramontina, J.; Kauer-Sant'anna, M.; Grassi-Oliveira, R.; Post, R.M. Allostatic load in bipolar disorder: Implications for pathophysiology and treatment. Neurosci. Biobehav. Rev. 2008, 32, 675-692. [CrossRef]

109. Danhof-Pont, M.B.; van Veen, T.; Zitman, F.G. Biomarkers in burnout: A systematic review. J. Psychosom. Res. 2011, 70, 505-524. [CrossRef]

110. Pochwat, B.; Szewczyk, B.; Sowa-Kucma, M.; Siwek, A.; Doboszewska, U.; Piekoszewski, W.; Gruca, P.; Papp, M.; Nowak, G. Antidepressant-like activity of magnesium in the chronic mild stress model in rats: Alterations in the NMDA receptor subunits. Int. J. Neuropsychopharmacol. 2014, 17, 393-405. [CrossRef]

111. Vink, R. Magnesium in the CNS: Recent advances and developments. Magnes. Res. 2016, $29,95-101$. [CrossRef] [PubMed]

112. Zheltova, A.A.; Kharitonova, M.V.; Iezhitsa, I.N.; Spasov, A.A. Magnesium deficiency and oxidative stress: An update. Biomed. Taipei 2016, 6, 20. [CrossRef] [PubMed]

113. Brosschot, J.F.; Verkuil, B.; Thayer, J.F. The default response to uncertainty and the importance of perceived safety in anxiety and stress: An evolution-theoretical perspective. J. Anxiety. Disord. 2016, 41, 22-34. [CrossRef] [PubMed]

114. Somjen, G.G.; Baskerville, E.N. Effect of Excess Magnesium on Vagal Inhibition and Acetylcholine Sensitivity of the Mammalian Heart in situ and in vitro. Nature 1968, 217, 679-680. [CrossRef]

115. Toda, N.; West, T. Interaction between $\mathrm{Na}, \mathrm{Ca}, \mathrm{Mg}$, and vagal stimulation in the S-A node of the rabbit. Am. J. Physiol. Leg. Content 1967, 212, 424-430. [CrossRef]

116. Murasato, Y.; Harada, Y.; Ikeda, M.; Nakashima, Y.; Hayashida, Y. Effect of Magnesium Deficiency on Autonomic Circulatory Regulation in Conscious Rats. Hypertension 1999, 34, 247-252. [CrossRef]

117. Brosschot, J.F.; Verkuil, B.; Thayer, J.F. Generalized Unsafety Theory of Stress: Unsafe Environments and Conditions, and the Default Stress Response. Int. J. Environ. Res. Public Health 2018, 15, 464. [CrossRef]

118. Stoian, M.; Stoica, V. The role of distubances of phosphate metabolism in metabolic syndrome. Maedica Buchar. 2014, 9, 255-260. [CrossRef]

119. Brosschot, J.F. Ever at the ready for events that never happen. Eur. J. Psychotraumatol. 2017, 8, 1309934. [CrossRef] 
120. Kirkland, A.E.; Sarlo, G.L.; Holton, K.F. The Role of Magnesium in Neurological Disorders. Nutrients 2018, 10, 730. [CrossRef]

121. Lopresti, A.L. The Effects of Psychological and Environmental Stress on Micronutrient Concentrations in the Body: A Review of the Evidence. Adv. Nutr. 2019, 11, 103-112. [CrossRef] [PubMed]

122. Classen, H.G.; Marquardt, P.; Späth, M.; Schumacher, K.A. Hypermagnesemia Following Exposure to Acute Stress. Pharmacology 1971, 5, 287-294. [CrossRef] [PubMed]

123. Ising, H.; Handrock, M.; Günther, T.; Fischer, R.; Dombrowski, M. Increased noise trauma in guinea pigs through magnesium deficiency. Arch. Oto Rhino Laryngol. 1982, 236, 139-146. [CrossRef] [PubMed]

124. Joachims, Z.; Babisch, W.; Ising, H.; Günther, T.; Handrock, M. Dependence of noise-induced hearing loss upon perilymph magnesium concentration. J. Acoust. Soc. Am. 1983, 74, 104-108. [CrossRef] [PubMed]

125. Ising, H. Interaction of noise-induced stress and Mg decrease. Artery 1981, 9, 205-211.

126. Ando, I.; Karasawa, K.; Yokota, S.; Shioya, T.; Matsuda, H.; Tanaka, A. Analysis of serum magnesium ions in dogs exposed to external stress: A pilot study. Open Vet. J. 2017, 7, 367-374. [CrossRef]

127. Yasmin, F.; Haleem, D.J.; Haleem, M.A. Effects of repeated restraint stress on serum electrolytes in ethanol-treated and water-treated rats. Pak. J. Pharm. Sci. 2007, 20, 51-55.

128. Heroux, O.; Peter, D.; Heggtveit, A. Long-term Effect of Suboptimal Dietary Magnesium on Magnesium and Calcium Contents of Organs, on Cold Tolerance and on Lifespan, and its Pathological Consequences in Rats. J. Nutr. 1977, 107, 1640-1652. [CrossRef]

129. Terashima, Y.; Tucker, R.E.; Deetz, L.E.; Degregorio, R.M.; Muntifering, R.B.; Mitchell, G.E., Jr. Plasma Magnesium Levels as Influenced by Cold Exposure in Fed or Fasted Sheep. J. Nutr. 1982, 112, 1914-1920. [CrossRef]

130. Whyte, K.F.; Addis, G.J.; Whitesmith, R.; Reid, J.L. Adrenergic control of plasma magnesium in man. Clin. Sci. Lond. 1987, 72, 135-138. [CrossRef]

131. Tanabe, K.; Osada, N.; Suzuki, N.; Nakayama, M.; Yokoyama, Y.; Yamamoto, A.; Oya, M.; Murabayashi, T.; Yamamoto, M.; Omiya, K.; et al. Erythrocyte magnesium and prostaglandin dynamics in chronic sleep deprivation. Clin. Cardiol. 1997, 20, 265-268. [CrossRef] [PubMed]

132. Takase, B.; Akima, T.; Uehata, A.; Ohsuzu, F.; Kurita, A. Effect of chronic stress and sleep deprivation on both flow-mediated dilation in the brachial artery and the intracellular magnesium level in humans. Clin. Cardiol. 2004, 27, 223-227. [CrossRef] [PubMed]

133. Mocci, F.; Canalis, P.; Tomasi, P.A.; Casu, F.; Pettinato, S. The effect of noise on serum and urinary magnesium and catecholamines in humans. Occup. Med. 2001, 51, 56-61. [CrossRef] [PubMed]

134. Ising, H.; Dienel, D.; Günther, T.; Markert, B. Health effects of traffic noise. Int. Arch. Occup. Environ. Health 1980, 47, 179-190. [CrossRef]

135. Joborn, H.; Akerström, G.; Ljunghall, S. Effects of exogenous catecholamines and exercise on plasma magnesium concentrations. Clin. Endocrinol. 1985, 23, 219-226. [CrossRef]

136. Caddell, J.; Kupiecki, R.; Proxmire, D.; Satoh, P.; Hutchinson, B. Plasma Catecholamines in Acute Magnesium Deficiency in Weanling Rats. JN 1986, 116, 1896-1901. [CrossRef]

137. Amyard, N.; Leyris, A.; Monier, C.; Francès, H.; Boulu, R.G.; Henrotte, J.G. Brain catecholamines, serotonin and their metabolites in mice selected for low (MGL) and high (MGH) blood magnesium levels. Magnes. Res. $1995,8,5-9$.

138. Henrotte, J.G.; Franck, G.; Santarromana, M.; Frances, H.; Mouton, D.; Motta, R. Mice selected for low and high blood magnesium levels: A new model for stress studies. Physiol. Behav. 1997, 61, 653-658. [CrossRef]

139. Henrotte, J.G.; Aymard, N.; Allix, M.; Boulu, R.G. Effect of pyridoxine and magnesium on stress-induced gastric ulcers in mice selected for low or high blood magnesium levels. Ann. Nutr. Metab. 1995, 39, $285-290$. [CrossRef]

140. Sartori, S.B.; Whittle, N.; Hetzenauer, A.; Singewald, N. Magnesium deficiency induces anxiety and HPA axis dysregulation: Modulation by therapeutic drug treatment. Neuropharmacology 2012, 62, 304-312. [CrossRef]

141. Bourin, M.; Hascoët, M. The mouse light/dark box test. Eur. J. Pharmacol. 2003, 463, 55-65. [CrossRef]

142. Spasov, A.A.; Iezhitsa, I.N.; Kharitonova, M.V.; Kravchenko, M.S. Depression-like and anxiety-related behaviour of rats fed with magnesium-deficient diet. Zhurnal Vysshei Nervnoi Deiatelnosti Imeni IP Pavlova 2008, 58, 476-485. 
143. Iezhitsa, I.N.; Spasov, A.A.; Kharitonova, M.V.; Kravchenko, M.S. Effect of magnesium chloride on psychomotor activity, emotional status, and acute behavioural responses to clonidine, d-amphetamine, arecoline, nicotine, apomorphine, and L-5-hydroxytryptophan. Nutr. Neurosci. 2011, 14, 10-24. [CrossRef] [PubMed]

144. Akarachkova, E. The role of magnesium deficiency in the formation of clinical manifestation of stress in women. Probl. Women Health 2013, 8, 57.

145. Nielsen, F.H.; Johnson, L.K.; Zeng, H. Magnesium supplementation improves indicators of low magnesium status and inflammatory stress in adults older than 51 years with poor quality sleep. Magnes. Res. 2010, 23, 158-168. [CrossRef]

146. Hermes Sales, C.; Azevedo Nascimento, D.; Queiroz Medeiros, A.C.; Costa Lima, K.; Campos Pedrosa, L.F.; Colli, C. There is chronic latent magnesium deficiency in apparently healthy university students. Nutr. Hosp. 2014, 30, 200-204. [CrossRef]

147. Eby, G.A.; Eby, K.L. Magnesium for treatment-resistant depression: A review and hypothesis. Med. Hypotheses 2010, 74, 649-660. [CrossRef]

148. Forsyth, A.K.; Williams, P.G.; Deane, F.P. Nutrition status of primary care patients with depression and anxiety. Aust. J. Prim. Health 2012, 18, 172-176. [CrossRef]

149. Abumaria, N.; Yin, B.; Zhang, L.; Li, X.Y.; Chen, T.; Descalzi, G.; Zhao, L.; Ahn, M.; Luo, L.; Ran, C.; et al. Effects of elevation of brain magnesium on fear conditioning, fear extinction, and synaptic plasticity in the infralimbic prefrontal cortex and lateral amygdala. J. Neurosci. 2011, 31, 14871-14881. [CrossRef]

150. Pochwat, B.; Sowa-Kucma, M.; Kotarska, K.; Misztak, P.; Nowak, G.; Szewczyk, B. Antidepressant-like activity of magnesium in the olfactory bulbectomy model is associated with the AMPA/BDNF pathway. Psychopharmacology 2015, 232, 355-367. [CrossRef]

151. Pilchova, I.; Klacanova, K.; Tatarkova, Z.; Kaplan, P.; Racay, P. The Involvement of Mg(2+) in Regulation of Cellular and Mitochondrial Functions. Oxid Med. Cell Longev. 2017, 2017, 6797460. [CrossRef] [PubMed]

152. Zogović, D.; Pesić, V.; Dmitrasinović, G.; Dajak, M.; Plećas, B.; Batinić, B.; Popović, D.; Ignjatović, S. Pituitary-gonadal, pituitary-adrenocortical hormonal and IL-6 levels following long-term magnesium supplementation in male students. J. Med. Biochem. 2014, 33, 291-298. [CrossRef]

153. Wienecke, E.; Nolden, C. Long-term HRV analysis shows stress reduction by magnesium intake. MMW Fortschr. Med. 2016, 158, 12-16. [CrossRef] [PubMed]

154. Pouteau, E.; Kabir-Ahmadi, M.; Noah, L.; Mazur, A.; Dye, L.; Hellhammer, J.; Pickering, G.; Dubray, C. Superiority of magnesium and vitamin B6 over magnesium alone on severe stress in healthy adults with low magnesemia: A randomized, single-blind clinical trial. PLoS ONE 2018, 13, e0208454. [CrossRef] [PubMed]

155. Eby, G.A.; Eby, K.L. Rapid recovery from major depression using magnesium treatment. Med. Hypotheses 2006, 67, 362-370. [CrossRef]

156. Boyle, N.B.; Lawton, C.; Dye, L. The Effects of Magnesium Supplementation on Subjective Anxiety and Stress-A Systematic Review. Nutrients 2017, 9, 429. [CrossRef]

Publisher's Note: MDPI stays neutral with regard to jurisdictional claims in published maps and institutional affiliations.

(C) 2020 by the authors. Licensee MDPI, Basel, Switzerland. This article is an open access article distributed under the terms and conditions of the Creative Commons Attribution (CC BY) license (http://creativecommons.org/licenses/by/4.0/). 